
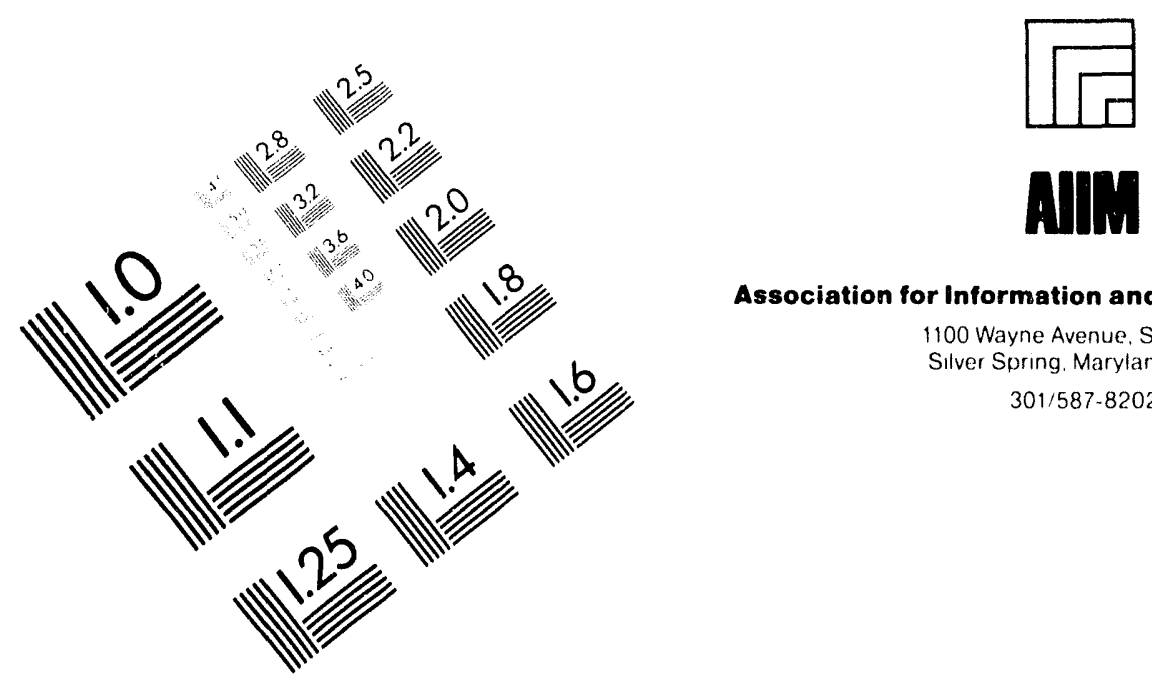

Association for Information and Image Management

1100 Wayne Avenue, Suite 1100

Silver Spring. Maryland 20910

301/587-8202

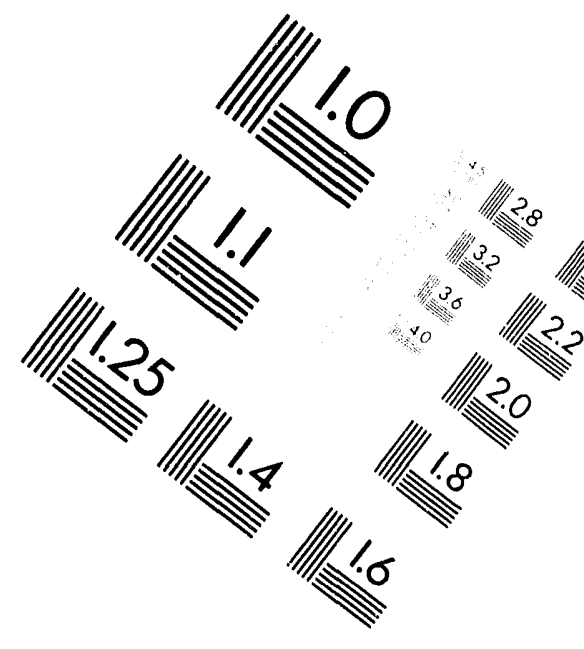

Centimeter

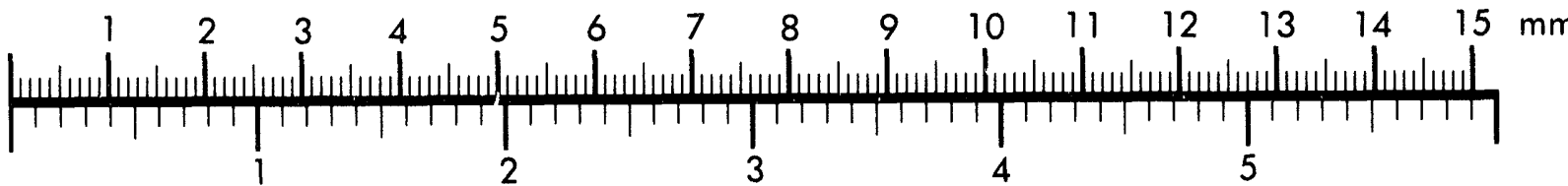

Inches
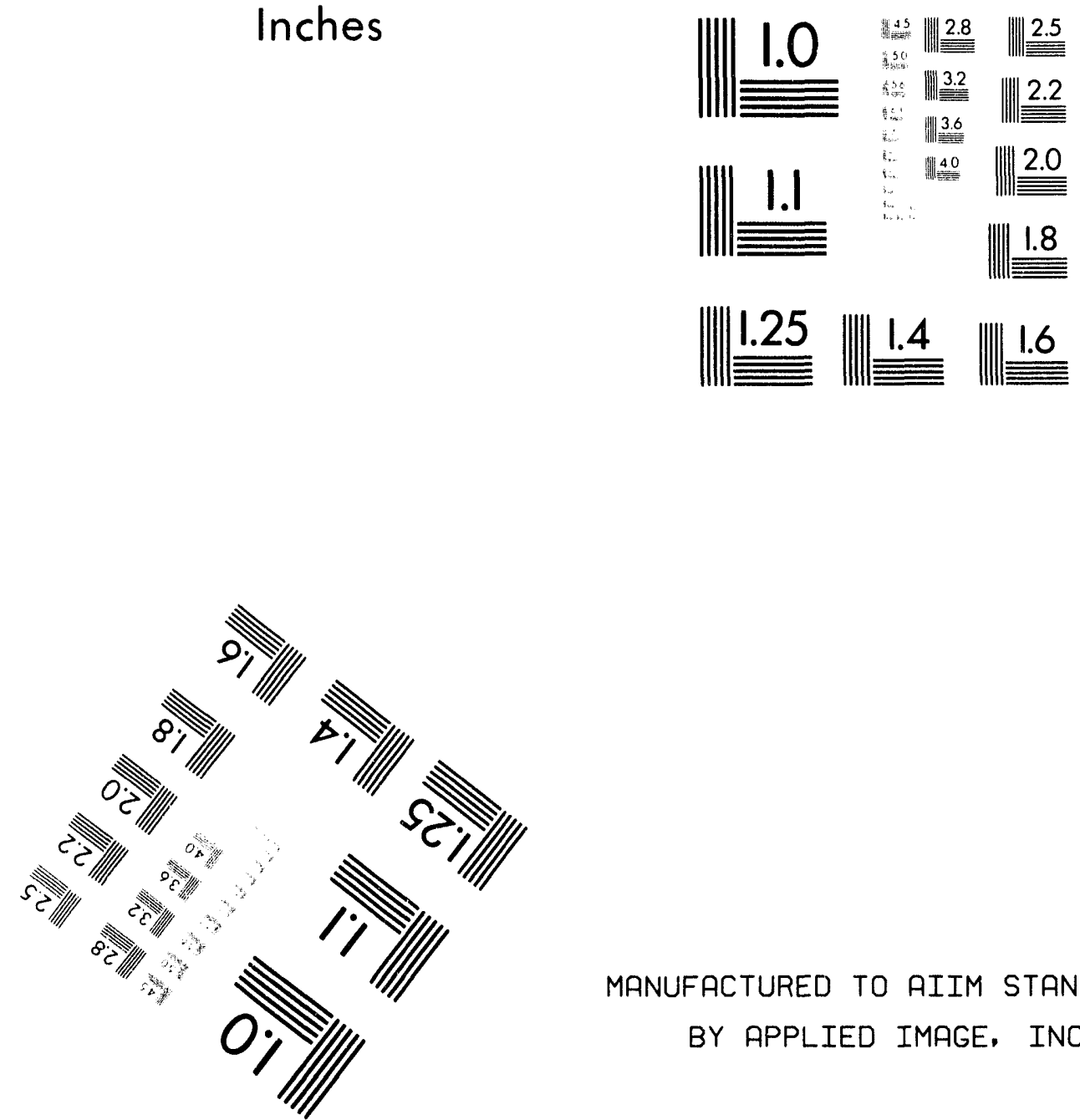

MANUFACTURED TO AIIM STANDARDS

BY APPLIED IMAGE. INC.

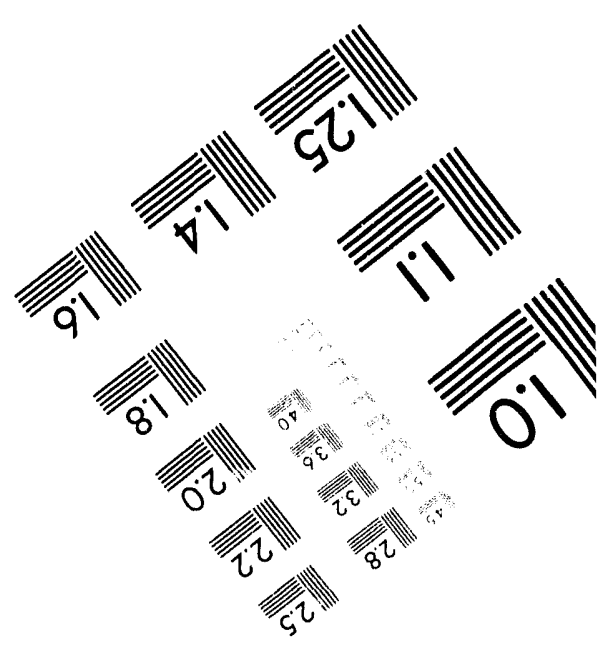



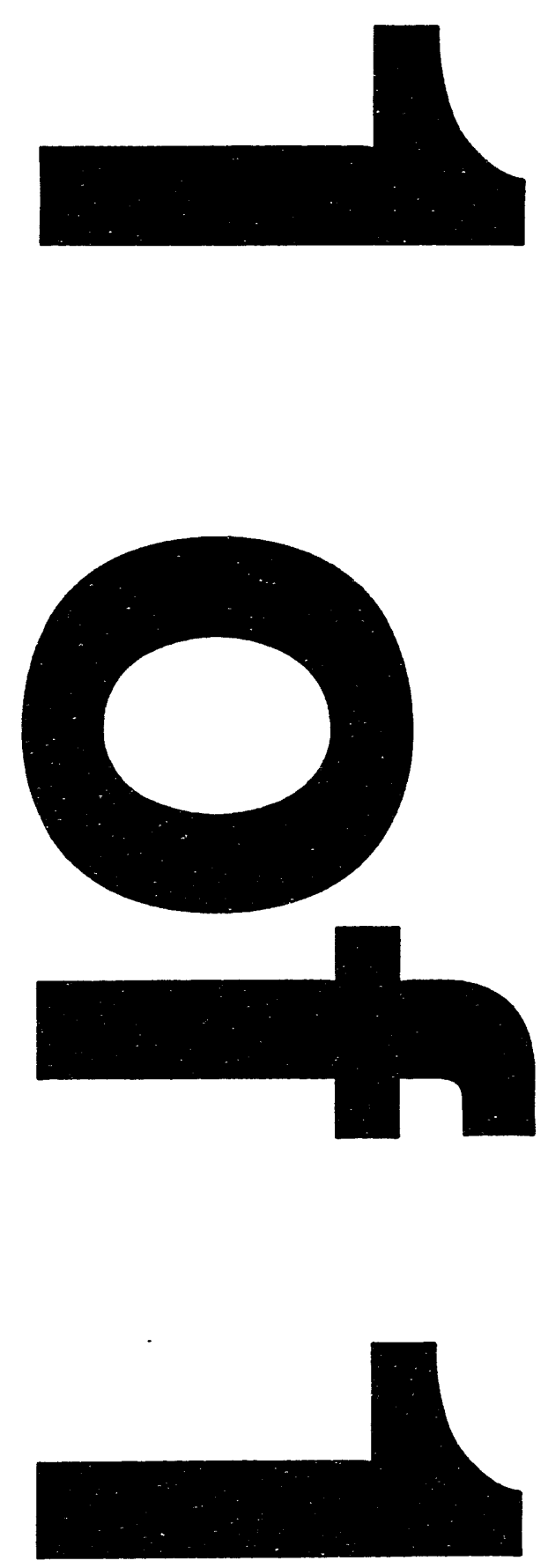

DuPage County, Illinois

Environmental Assessment Division Argonne National Laboratory

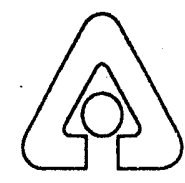

Operated by the University of Chicago, under Contract W-31-109-Eng-38, for the United States Department of Energy 


\section{Argonne National Laboratory}

Argonne National Laboratory, with facilities in the states of Illinois and Idaho, is owned by the United States Govemment, and operated by the University of Chicago under the provisions of a contract with the Department of Energy.

This technical memo is a product of Argonne's Environmental Assessment Division (EAD). For information on the divișion's scientific and engineering activities, contact:

Director, Environmental Assessment Division

Arjonne National Laboratory

Argonne, Illinois 60439-4815

Telephone (708) 252-3107

Presented in this technical memo are preliminary results of ongoing work or work that is more limited in scope and depth than that described in formal reports issued by the EAD.

\section{Disclaimer}

This report was prepared as an account of work sponsored by an agency of the United States Government. Neither the United States Govemment nor any agency thereof, nor any of their employees, makes any warranty, express or implied, or assumes any legal liability or responsibility for the accuracy, completeness, or usefulness of any information, apparatus, product, or process disclosed, or represents that its use would not infringe privately owned rights. Reference herein to any specific commercial product, process, or service by trade name, trademark, manufacturer, or otherwise, does not necessarily constitute or imply its endorsement, recommendation, or favoring by the United States Govemment or any agency thereof. The views and opinions of authors expressed herein do not necessarily state or reflect those of the United States Govemment or any agency thereof. 


\section{Wetlands of frgonne National Laboratory-East, DuPage County, Illinois}

by R.A. Van Lonkhuyzen and K.E. LaGory

Ecological Sciences Section,

Environmental Assessment Division,

Argonne National Laboratory, 9700 South Cass Avenue, Argonne, Illinois 60439

March 1994

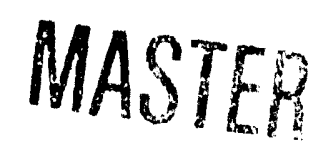




\section{CONTENTS}

ACKNOWLEDGMENTS $\ldots \ldots \ldots \ldots \ldots \ldots \ldots \ldots \ldots \ldots \ldots \ldots$ iv

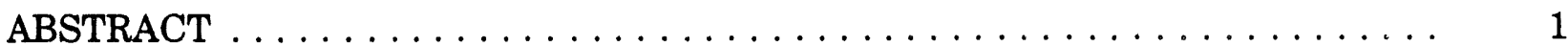

1 INTRODUCTION $\ldots \ldots \ldots \ldots \ldots \ldots \ldots \ldots \ldots \ldots \ldots \ldots \ldots$

2 SITE DESCRIPTION $\ldots \ldots \ldots \ldots \ldots \ldots \ldots \ldots \ldots \ldots \ldots \ldots \ldots \ldots \ldots$

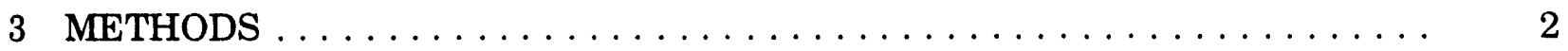

4 RESULTS $\ldots \ldots \ldots \ldots \ldots \ldots \ldots \ldots \ldots \ldots \ldots \ldots \ldots \ldots \ldots$

5 DISCUSSION $\ldots \ldots \ldots \ldots \ldots \ldots \ldots \ldots \ldots \ldots \ldots \ldots \ldots \ldots$

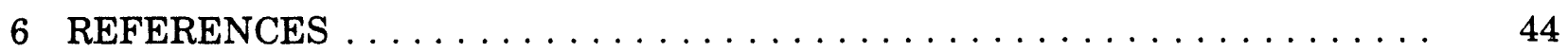

\section{TABLE}

1 Plant Indicator Status Categories $\ldots \ldots \ldots \ldots \ldots \ldots \ldots \ldots \ldots \ldots \ldots \ldots$

\section{PI_ATE}

1 Wetlands at ANL-E $\ldots \ldots \ldots \ldots \ldots \ldots \ldots \ldots \ldots \ldots \ldots \ldots$ 


\section{ACKNOWLEDGMENTS}

The authors thank Julie Whitacre, Donald Meissner, and Robert Boer for assistance with field work. 


\title{
WETLANDS OF ARGONNE NATIONAL LABORATORY-EAST, DUPAGE COUNTY, ILLINOIS
}

by

\author{
R.A. Van Lonkhuyzen and K.E. LaGory
}

\begin{abstract}
Jurisdictional wetlands of the Argonne National Laboratory-East (ANL-E) site in DuPage County, Illinois, were delineated in the summer and autumn of 1993 in accordance with the 1987 U.S. Army Corps of Engineers methodology. Potential wetland sites with an area greater than $500 \mathrm{~m}^{2}$ ( 0.05 ha [0.124 acre]) were identified for delineation on the basis of aerial photographs, the DuPage County soil survey, and reconnaissance-level field studies. To qualify as a jurisdictional wetland, an area had to support a predominance of hydrophytic vegetation as well as have hydric soil and wetland hydrology. Thirty-five individual jurisdictional wetlands were delineated at ANL-E, totaling $180,604 \mathrm{~m}^{2}$ (18.1 ha [44.6 acres]). These wetlands were digitized onto the ANL-E site map for use in project planning. Characteristics of each wetland are presented - including size, dominant plant species and their indicator status, hydrologic characteristics (including water source), and soil characteristics.
\end{abstract}

\section{INTRODUCTION}

Section 404 of the Clean Water Act authorizes the U.S. Army Corps of Engineers (Corps) to regulate the discharge of dredge or fill material into waters of the United States. Included in "waters of the U.S." are wetlands and other special aquatic sites. For purposes of administering the Section 404 program, the Corps defines wetlands as follows:

Those areas that are inundated or saturated by surface or groundwater at a frequency and duration sufficient to support, and that under normal circumstances do support, a prevalence of vegetation typically adapted for life in saturated soil conditions. Wetlands generally include swamps, marshes, bogs, and similar areas.

The Corps has developed a methodology for defining the boundaries of (delineating) such jurisdictional wetlands (Environmental Laboratory 1987).

To facilitate project planning at Argonne National Laboratory-East (ANL-E), a research and development facility of the U.S. Department of Energy, a sitewide delineation of jurisdictional wetlands on the laboratory grounds was performed in the summer and fall 
of 1993. This report presents the methodology used to delineate the ANL-E wetlands and describes the characteristics of these wetlands - including size, location, dominant plant species, soil characteristics, and hydrological characteristics.

\section{SITE DESCRIPTION}

The ANL-E site occupies about 689 ha (1,700 acres) of land and is located about $40 \mathrm{~km}(25 \mathrm{mi})$ southwest of Chicago in DuPage County, Illinois. The ANL-E research and development facility has been in operation since the late 1940s and contains a number of laboratory, office, and support buildings, parking lots, and roadways. Developed areas (including mowed lawns and fire lanes) occupy about 425 ha (1,050 acres). The remaining 264 ha (650 acres) are relatively undisturbed woodlots, old fields, and wetlands.

The Waterfall Glen Forest Preserve, covering 809 ha (2,000 acres), surrounds the ANL-E property and serves as a public recreation area and nature preserve. The forest preserve contains much of the same vegetation types as are present on the ANL-E site, and both areas are within the drainage basin of Sawmill Creek, a tributary of the Des Plaines River. The preserve includes about 105 ha (260 acres) of wetlands. Additional wetlands occur along the Des Plaines River to the south of the forest preserve and ANL-E.

Lands surrounding ANL-E and Waterfall Glen Forest Preserve have experienced rapid development over the last two decades. Most of this development has been construction of residential dwellings, office space, and retail businesses. This development has resulted in a marked alteration of the landscape, much of which had been used previously for agricultural purposes, and a loss or alteration of drainage patterns and wetlands. This development increases the importance of existing wetlands, such as those at ANL-E and Waterfall Glen Forest Preserve.

\section{METHODS}

Potential wetlands at ANL-E with an area greater than $500 \mathrm{~m}^{2}(0.05$ ha $[0.124$ acre] $)$ were identified on the basis of aerial photographs, the DuPage County soil survey (Soil Conservation Service 1979), and reconnaissance-level field studies. Wetland boundaries were delineated in accordance with the currently approved methodology described in the 1987 Corps of Engineers Wetlands Delineation Manual (Environmental Laboratory 1987) and subsequent guidance issued by the Corps. To qualify as a wetland with this methodology, an area must have hydric soil and wetland hydrology, and must support a predominance of hydrophytic vegetation.

The method for routine determination was followed (Section D, Subsection 2, of the Wetlands Delineation Manual). Plant communities were determined at each site, and data were collected at a representative location within each community. If a community occupied 
a relatively large proportion of a site or bordered upland communities at widely separated locations, data were collected at more than one location within the community. If the boundary between wetland and upland communities was indistinct, data were collected near the apparent boundary to produce more accurate delineations.

Data collected at each location included dominant plant species (after Swink and Wilhelm 1979), hydrological conditions, and soil characteristics. A standard data sheet was used for each location. Dominant plant species were determined for the following strata: herbs, trees, shrubs and saplings, and woody vines. Dominance was based on percent areal coverage. The hydrophytic vegetation parameter was considered met if more than $50 \%$ of all dominant plant species had an indicator status of facultative, facultative wetland, or obligate wetland. The indicator status of plant species was determined from Reed (1988). The status categories are defined in Table 1.

Hydrological conditions were determined at each sampling location. Depth to water table was determined with a steel soil probe $2 \mathrm{~cm}(0.75 \mathrm{in}$.) in diameter. Soil cores were obtained by using the probe, and depth to water was measured in the probe hole. The

TABLE 1 Plant Indicator Status Categories

\begin{tabular}{lll}
\hline \multicolumn{1}{c}{ Indicator Category } & $\begin{array}{c}\text { Indicator } \\
\text { Symbol }\end{array}$ & \multicolumn{1}{c}{ Definition } \\
\hline Obligate wetland plants & OBL & $\begin{array}{l}\text { Plants that occur almost always in wetlands under } \\
\text { natural conditions (estimated probability }>99 \%), \text { but } \\
\text { may also occur rarely in nonwetlands (estimated } \\
\text { probability <1\%) }\end{array}$ \\
Facultative wetland plants & FACW & $\begin{array}{l}\text { Plants that occur usually in wetlands (estimated } \\
\text { probability }>67 \text { to 99\%), but also occur in } \\
\text { nonwetlands (estimated probability 1 to 33\%) }\end{array}$ \\
Facultative plants & FAC & $\begin{array}{l}\text { Plants with a similar likelihood of occurring in both } \\
\text { wetlands and nonwetlands (estimated probability 33 } \\
\text { to 67\%) }\end{array}$ \\
Facultative upland plants & FACU & $\begin{array}{l}\text { Plants that occur sometimes in wetlands (estimated } \\
\text { probability 1 to <33\%), but occur more often in } \\
\text { nonwetlands (estimated probability }>67 \text { to 99\%) }\end{array}$ \\
Obligate upland plants & UPL & $\begin{array}{l}\text { Plants that occur rarely in wetlands (estimated } \\
\text { probability <1\%), but occur almost always in } \\
\text { nonwetlands under natural conditions (estimated } \\
\text { probability }>99 \%)\end{array}$ \\
\hline
\end{tabular}

a The three facultative categories may be subdivided by "+" (more wet) or "-" (less wet).

Source: Environmental Laboratory (1987). 
wetland hydrology parameter was considered met if at least one primary indicator, or two secondary indicators, were present (Environmental Laboratory 1987). Primary indicators were (1) inundation; (2) saturated soil within $30 \mathrm{~cm}$ (12 in.) of the soil surface; (3) water marks, drift lines, or sediment deposits on surface features; and (4) drainage patterns in wetlands. Secondary indicators were (1) oxidized root channels within $30 \mathrm{~cm}$ (12 in.) of the soil surface; (2) water-stained leaves; (3) local soil survey data; and (4) a positive facultativeneutral test (more than $50 \%$ of dominant species wetter than facultative).

Soils were collected for examination at each location with the soil probe or a spade. Soil color was determined according to the Munsell Soil Color Charts (Kollmorgen Corporation 1990). Matrix culor, mottle color and abundance, and soil texture were recorded for each soil horizon or at a depth of $25 \mathrm{~cm}$ (10 in.). The hydric soil parameter was considered met if at least one of the following hydric indicators was present: (1) histosol, (2) histic epipedon, (3) sulfidic odor, (4) aquic moisture regime, (5) reducing conditions, (6) gleyed or low-chroma colors (at $25 \mathrm{~cm}$ [10 in.] or immediately below the A horizon), (7) concretions, (8) high organic content in the surface layer in sandy soils, (9) organic streaking in sandy soils, (10) soil listed on the local hydric soils list, or (11) soil listed on the national hydric soils list. Soils were assumed to be hydric if all dominant plant species at the location were obligate wetland species or if all dominants were obligate wetland and facultative wetland species and the wetland/upland boundary was abrupt (Environmental Laboratory 1987). Soils that were known to be inundated for a long time during the growing season (i.e., more than two weeks) were considered to be hydric, as allowed in the Wetlands Delineation Manual.

Communities in which all three wetland parameters were met were considered wetland. Wetland boundaries were drawn around contiguous wetland plant communities. Where this boundary was indistinct, the wetland boundary was established between two data collection points, one upland and one wetland.

Wetland boundaries were digitized onto the ANL-E site map from aerial photographs taken on March 19, 1992. Locations of wetland boundaries were verified in the field.

\section{RESULTS}

The delineation of wetlands at ANL-E identified 35 wetlands with a total area of approximately $180,604 \mathrm{~m}^{2}$ (8.06 ha [44.6 acres]) on the ANL-E site. In addition, a relatively large wetland (4.1 ha [10.2 acres]) was delineated adjacent to the ANL-E boundary in Waterfall Glen Forest Preserve. The locations and boundaries of these wetlands at the time of the survey are shown in Plate 1 (inserted at the back of the report). Wetlands are numbered consecutively within ANL-E building areas by a three-digit code; for example, the eight wetlands in the 200 Area of the laboratory are numbered 201 through 208.

The delineated wetlands represent a variety of types, including (1) floodplain or riparian wetlands (e.g., 002 and 103); (2) forested wetlands (e.g., 101 and 307); and (3) marshes, dominated by cat-tails, grasses, sedges, and rushes (e.g., 201 and 406). Some 
of the wetlands are of relatively recent origin and have been formed as a result of human or beaver activities. Beaver dams have created five wetlands along intermittent streams at ANL-E (numbers 201, 302, 303, 402, and 803); these wetlands total 9.1 ha (22.6 acres).

Some wetlands on the ANL-E site are relatively disturbed, including five wetlands $(203,204,205,206$, and 208) and parts of two others (306 and 802) that are along drainage ditches (total area approximately 0.6 ha [1.5 acres]). These wetlands show atypical soil profiles that reflect past disturbance and generally support degraded plant communities with relatively weedy species and low species diversity. Several disturbed wetlands are near active construction sites (e.g., wetlands 304 and 406) and have experienced altered hydrological conditions or received sediments eroded from the construction area. These wetlands are undergoing changes in species composition as they become drier.

Several high-quality, relatively undisturbed wetlands that support unusual plant species or high species diversity were also delineated. Wetlands 401 through 405 , in the southwest part of the ANL-E site, support relatively complex plant communities with high species diversity. Hairy marsh cress (Rorippa islandica hispida), listed as threatened in Illinois, was found at wetlands 402 and 406; Engelmann's flatsedge (Cyperus engelmanni), a rare wetland species, at wetland 201; and bristly smartweed (Polygonum setaceum interjectum), another rare species, at wetland 301 .

A summary of information regarding each delineated jurisdictional wetland at ANL-E is provided on the following pages. 
Wetland Number: 001

Size: $854 \mathrm{~m}^{2}(0.211$ acre $)$

Dominant Plant Species:

Scientific Name

Phalaris arundinacea
Common Name

Reed canary grass
Indicator

Status

FACW+

\section{Hydrology:}

Hydrologic Regime: Surface water occurs in spring in the intermittent stream that flows through the wetland and near the culvert running beneath Front Street.

The rest of the wetland is saturated to the surface in spring.

Water Source(s): Unnamed intermittent stream running southwest from Waterfall Glen Forest Preserve and a drainage ditch running east along Front Street.

\section{Soil:}

Map Unit Name:

Inclusion:

Taxonomy:

Drainage Class:

Matrix Color:
Morley silt loam

Ashkum

Typic Haplaquoll

Poorly drained

10 YR 2.5/1 
Wetland Number: 002

Size: $16,618 \mathrm{~m}^{2}$ (4.106 acres)

Dominant Plant Species:

Scientific Name

Phalaris arundinacea

Tilia americana

Ulmus americana
Common Name

Reed canary grass

Basswood

American elm
Indicator

Status

FACW+

FACU

FACW-

\section{Hydrology:}

Hydrologic Regime: Surface water is frequently present in spring, and soil is saturated within $30 \mathrm{~cm}$ (12 in.) of the surface for extended periods in spring.

Water Source(s): Primarily the annual floodwaters of Sawmill Creek. Freund Brook also passes through the southern portion of the site.

Soil:

Map Unit Name:

Inclusion:

Taxonomy:

Drainage Class:

Matrix Color:
Sawmill silty clay loam

Undetermined

Cumulic Haplaquoll

Poorly drained

10 YR 3/1.5, 10 YR 3/2 
Wetland Number: 101

Size: $1,405 \mathrm{~m}^{2}(0.347$ acre $)$

Dominant Plant Species:

$\underline{\text { Scientific Name }}$

Acer negundo

Boehmeria cylindrica

Fraxinus pennsylvanica

Leersia virginica

Pilea pumila

Polygonum punctatum

Populus deltoides

Ulmus americana
Common Name

Box elder

False nettle

Red ash

White grass

Clearweed

Smartweed

Cottonwood

American elm
Indicator

Status

FACW-

OBL

FACW

FACW

FACW

OBL

FAC+

FACW-

\section{Hydrology:}

Hydrologic Regime: Surface water is present throughout the site for extended periods in spring.

Water Source(s): Seasonally high water table and surface flow from the surrounding area.

Soil:

Map Unit Name:

Sawmill silty clay loam

Inclusion:

Undetermined

Taxonomy:

Cumulic Haplaquoll

Drainage Class:

Poorly drained

Matrix Color:

10 YR 2.5/1, 10 YR 3.5/1 
Wetland Number: 102

Size: $1,799 \mathrm{~m}^{2}(0.445$ acre $)$

Dominant Plant Species:

Scientific Name

Agrostis alba

Carex cristatella

Carex lanuginosa

Carex trichocarpa

Fraxinus pennsylvanica subintegerrima

Iris virginica shrevei

Juncus tenuis

Juncus torreyi

Phalaris arundinacea

Poa pratensis

Rhus radicans

Salix nigra

Solidago graminifolia nuttallii

Vitis riparia
Common Name

Redtop

Crested sedge

Wooly sedge

Hairy-fruit sedge

Green ash

Blue flag

Roadside rush

Torrey's rush

Reed canary grass

Kentucky blue grass

Poison ivy

Black willow

Grass-leaved goldenrod

Riverbank grape
Indicator

Status

FACW

FACW+

OBL

OBL

FACW

OBL

FAC

FACW

FACW+

FAC-

FAC+

OBL

FAC

FACW-

\section{Hydrology:}

Hydrologic Regime: Surface water is present in the eastern portion of the site in spring. Soil in the remainder of the wetland is saturated within $30 \mathrm{~cm}$ (12 in.) of the surface for extended periods in spring.

Water Source(s): A small intermittent stream entering the site from the southwest, surface runoff from the surrounding area, and a seasonally high water table.

Soil:

Map Unit Name: Inclusion:

Taxonomy: Drainage Class: Matrix Color:
Sawmill silty clay loam

Undetermined

Cumulic Haplaquoll

Poorly drained

10 YR 2/1, 10 YR 2/0, 10 YR 2.5/0.5, 10 YR 4/1 
Wetland Number: 103

Size: $4,858 \mathrm{~m}^{2}$ (1.200 acres)

Dominant Plant Species:

$\underline{\text { Scientific Name }}$

Phalaris arundinacea

Salix nigra
Common Name

Reed canary grass

Black willow
Indicator

Status

FACW+ OBL

\section{Hydrology:}

Hydrologic Regime: Surface water is present in spring. Soil is saturated to the surface for extended periods.

Water Source(s): Annual floodwaters of Sawmill Creek and surface flow from the surrounding area.

\section{Soil:}

Map Unit Name:

Inclusion:

Taxonomy:

Drainage Class:

Matrix Color:
Sawmill silty clay loam

Undetermined

Cumulic Haplaquoll

Poorly drained

10 YR 3/1 
Wetland Number: 201

Size: $16,820 \mathrm{~m}^{2}(4.156$ acres $)$

Dominant Plant Species:

$\underline{\text { Scientific Name }}$

Bidens frondosa

Cirsium arvense

Leersia oryzoides

Mentha arvensis villosa

Phalaris arundinacea

Polygonum punctatum

Typha latifolia
Common Name

Common beggar's ticks

Canada thistle

Rice cut grass

Wild mint

Reed canary grass

Smartweed

Common cat-tail
Indicator

Status

FACW

FACU

OBL

FACW

$\mathrm{FACW}+$

OBL

OBL

\section{Hydrology:}

Hydrologic Regime: Surface water is present throughout the year within the stream channels on the site. Areas not inundated are saturated within $30 \mathrm{~cm}$ (12 in.) of the surface for extended periods. A small area in the northwest part of the site is ponded by remnants of a beaver dam.

Water Source(s): An unnamed intermittent tributary of Sawmill Creek entering at the southern end of the site, storm sewer drainage from the areas of Buildings 206,207 , and 208 entering at the eastern end, and surface runoff from the surrounding area.

Soil:

Map Unit Name:

Inclusion:

Taxonomy:

Drainage Class:

Matrix Color:
Peotone silty clay loam, Beecher silt loam

Ashkum (in Beecher)

Cumulic Haplaquoll, Typic Haplaquoll

Very poorly drained, poorly drained

10 YR 2.5/1, 10 YR 3/1, 10 YR 2/1, 10 YR 2/0 
Wetland Number: 202

Size: $2,190 \mathrm{~m}^{2}(0.541$ acre $)$

Dominant Plant Species:

Scientific Name

Carex stricta

Poa pratensis

Solidago gigantea

Solidago graminifolia nuttallii

Typha angustifolia
Common Name

Upright sedge

Kentucky blue grass

Late goldenrod

Grass-leaved goldenrod

Narrow-leaved cat-tail
Indicator

Status

OBL

FAC-

FACW

FAC

OBL

\section{Hydrology:}

Hydrologic Regime: Surface water is present throughout the growing season. Areas not inundated are saturated within $30 \mathrm{~cm}$ (12 in.) of the surface for extended periods in spring.

Water Source(s): Storm sewer drainage from the area of Building 203 entering at the south end of the site and surface runoff from the surrounding area.

Soil:

Map Unit Name:

Inclusion:

Taxonomy:

Drainage Class:

Matrix Color:
Peotone silty clay loam

Undetermined

Cumulic Haplaquoll

Very poorly drained

10 YR 3/2, 10 YR 2/1 
Wetland Number: 203

Size: $1,328 \mathrm{~m}^{2}(0.328$ acre $)$

Dominant Plant Species:

$\underline{\text { Scientific Name }}$

Cyperus strigosus

Juncus torreyi

Salix interior

Scirpus atrovirens

Solidago graminifolia nuttallii

Spartina pectinata

Typha angustifolia
Common Name

Straw-color flatsedge

Torrey's rush

Sandbar willow

Dark green rush

Grass-leaved goldenrod

Prairie cord grass

Narrow-leaved cat-tail
Indicator

Status

FACW

FACW

OBL

OBL

FAC

FACW+

OBL

\section{Hydrology:}

Hydrologic Regime: Surface water is present throughout the growing season.

Water Source(s): Storm sewer drainage from the areas of Buildings 203 and 221 entering at the west end of the site and surface runoff from the surrounding area.

Soil:

Map Unit Name:

Inclusion:

Taxonomy:

Drainage Class:

Matrix Color:
Morley silt loam

Undetermined

Undetermined

Undetermined

2.5 Y 3.5/1, 2.5 Y 5/0, 10 YR 4/3.5 
Wetland Number: 204

Size: $580 \mathrm{~m}^{2}(0.143$ acre $)$

Dominant Plant Species:

Scientific Name

Acorus calamus

Leersia oryzoides

Scirpus atrovirens

Solidago graminifolia nuttallii

Typha angustifolia
Common Name

Sweetflag

Rice cut grass

Dark green rush

Grass-leaved goldenrod

Narrow-leaved cat-tail
Indicator

Status

OBL

OBL

OBL

FAC

OBL

\section{Hydrology:}

Hydrologic Regime: Surface water is present throughout the growing season within the drainage channel.

Water Source(s): Storm sewer drainage from the area of Building 202 entering at the west end of the site, drainage from wetland 205 entering at the east end, and surface runoff from the surrounding area.

Soil:

Map Unit Name:

Inclusion:

Taxonomy:

Drainage Class:

Matrix Color:
Morley silt loam, Ashkum silty clay loam

Ashkum

Typic Haplaquoll

Poorly drained

10 YR 2/1, 10 YR 3/2, 10 YR 4/3 
Wetland Number: 205

Size: $1,644 \mathrm{~m}^{2}(0.406$ acre $)$

Dominant Plant Species:

Scientific Name

Ribes americanum

Typha angustifolia
Common Name

Wild black currant

Narrow-leaved cat-tail
Indicator

Status

FACW

OBL

\section{Hydrology:}

Hydrologic Regime: Surface water is present throughout the growing season in the stream channel. Soil is saturated within $30 \mathrm{~cm}$ (12 in.) of the surface for extended periods in spring throughout the rest of the site.

Water Source(s): Storm sewer drainage from the area of Building 202 entering at the west end of the site and surface runoff from the surrounding area.

\section{Soil:}

Map Unit Name: Inclusion:

Taxonomy:

Drainage Class:

Matrix Color:
Ashkum silty clay loam, Morley silt loam Undetermined

Typic Haplaquoll

Poorly drained

2.5 Y 4/0, 10 YR 2/1, 2.5 Y 3.5/0 
Wetland Number: 206

Size: $622 \mathrm{~m}^{2}(0.154$ acre $)$

Dominant Plant Species:

Scientific Name

Solanum dulcamara Typha angustifolia
Common Name

Bittersweet nightshade Narrow-leaved cat-tail
Indicator

Status

FAC

OBL

\section{Hydrology:}

Hydrologic Regime: Surface water is present throughout the growing season. Areas not inundated are saturated within $30 \mathrm{~cm}$ (12 in.) of the surface for extended periods in spring.

Water Source(s): Storm sewer drainage from the area of Building 200 entering at the west end of the site, two undetermined drainages entering near the east end, and surface runoff from the surrounding area.

Soil:

Map Unit Name:

Inclusion:

Taxonomy:

Drainage Class:

Matrix Color:
Morley silt loam

Undetermined

Undetermined

Undetermined

10 YR 4/4, 10 YR 4/5 
Wetland Number: 207

Size: $1,301 \mathrm{~m}^{2}(0.321$ acre $)$

Dominant Plant Species:

$\underline{\text { Scientific Name }}$

Alliaria officinalis

Boehmeria cylindrica

Circaea quadrisulcata canadensis

Cirsium arvense

Cornus obliqua

Cornus racemosa

Eupatorium serotinum

Phragmites australis

Pilea pumila

Rhus radicans

Ribes americanum

Salix alba

Salix nigra

$\therefore$ umbucus canadensis

Typha angustifolia

Vitis riparia
Common Name

Garlic mustard

False nettle

Enchanter's nightshade

Canada thistle

Pale dogwood

Gray dogwood

Late boneset

Common reed

Clearweed

Poison ivy

Wild black currant

White willow

Black willow

Elderberry

Narrow-leaved cat-tail

Riverbank grape
Indicator

Status

FAC

OBL

FACU

FACU

FACW+

FACW-

$\mathrm{FAC}+$

FACW+

FACW

FAC+

FACW

FACW

OBL

FACW-

OBL

FACW.

\section{Hydrology:}

Hydrologic Regime: Surface water is present throughout the growing season within the stream channels. The remaining area is saturated within $30 \mathrm{~cm}$ (12 in.) of the surface for prolonged periods in spring.

Water Source(s): Storm sewer drainage from the areas of Buildings 201 and 213 and wetland 206 (which receives drainage from the area of Building 200) entering the site at the northwest end and another drainage from the area of Building 201 entering at the southwest end.

Soil:

Map Unit Name:

Inclusion:

Taxonomy:

Drainage Class:

Matrix Color:
Ashkum silty clay loam

Undetermined

Typic Haplaquoll

Poorly drained

10 YR 2.5/1, 10 YR 2/1, 10 YR 3/2, 10 YR 3/1.5 
Wetland Number: 208

Size: $1,148 \mathrm{~m}^{2}(0.284$ acre $)$

Dominant Plant Species:

Scientific Name

Typha angustifolia
Common Name

Narrow-leaved cat-tail
Indicator

Status

OBL

\section{Hydrology:}

Hydrologic Regime: Surface water is present throughout the growing season.

Water Source(s): Storm sewer system drainage from the area of Building 205 entering at the west end of the site and surface runoff from the surrounding area.

\section{Soil:}

Map Unit Name: Inclusion:

Taxonomy: Drainage Class:

Matrix Color:
Morley silt loam, Peotone silty clay loam Undetermined Undetermined Undetermined 10 YR 5/3, 2.5 Y 4/2, 2.5 Y 3.5/2 
Wetland Number: 301

Size: $1,807 \mathrm{~m}^{2}(0.447$ acre $)$

Dominant Plant Species:

Scientific Name

Agrostis alba

Carex bebbii

Carex cristatella

Carex vulpinoidea

Festuca elatior

Juncus torreyi

Scirpus atrovirens

Scirpus lineatus

Solidago graminifolia nuttallii

Spartina pectinata

Typha angustifolia

Typha latifolia
Common Name

Redtop

Bebb's sedge

Crested sedge

Fox sedge

Meadow fescue

Torrey's rush

Dark green rush

Red bulrush

Grass-leaved goldenrod

Prairie cord grass

Narrow-leaved cat-tail

Common cat-tail
Indicator

Status

FACW

OBL

FACW+

OBL

FACU-

FACW

OBL

OBL

FAC

FACW+

OBL

OBL

\section{Hydrology:}

Hydrologic Regime: Surface water is present throughout the year. Areas not inundated are saturated to the surface for extended periods.

Water Source(s): Drainage from Water Towers 565 and 566 (possibly due to leaks in the pumping system) entering the site at the northwest end.

\section{Soil:}

$\begin{array}{ll}\text { Map Unit Name: } & \text { Morley silt loam } \\ \text { Inclusion: } & \text { Undetermined } \\ \text { Taxonomy: } & \text { Undetermined } \\ \text { Drainage Class: } & \text { Undetermined } \\ \text { Matrix Color: } & 10 \text { YR } 2 / 1,10 \text { YR 4/2, 10 YR 5/1.5, } 10 \text { YR } 3 / 2\end{array}$


Wetland Number: 302

Size: $32,150 \mathrm{~m}^{2}$ (7.944 acres)

Dominant Plant Species:

Scientific Name

Alisma subcordatum

Bidens frondosa

Cyperus erythrorhizos

Echinochloa crusgalli

Leersia oryzoides

Lemna minor

Lycopus americanus

Penthorum sedoides

Phalaris arundinacea

Polygonum coccineum
Common Name

Common water plantain

Common beggar's ticks

Red-rooted sedge

Barnyard grass

Rice cut grass

Small duckweed

Common water horehound

Ditch stone crop

Reed canary grass

Water heartsease
Indicator

Status

OBL

FACW

OBL

FACW

OBL

OBL

OBL

OBL

FACW+

OBL

\section{Hydrology:}

Hydrologic Regime: Surface water is present throughout the year. Water levels are controlled by a beaver dam at the northeast end, where water flows into wetland 303. Areas not inundated are saturated within $30 \mathrm{~cm} \mathrm{(12} \mathrm{in.)} \mathrm{of} \mathrm{the}$ surface for extended periods. Water levels in this wetland vary considerably between years, depending on the condition of the beaver dam. Lower water levels allow wetland vegetation to colonize areas that under higher levels support only submergent aquatic plants and nonrooted floating plants.

Water Source(s): Freund Brook entering at the west side of the site, surface runoff from the surrounding area, an unnamed intermittent stream entering at the southwest end, and a channel from wetland 304 entering at the northeast (flows limited by a dam installed in the channel).

Soil:

Map Unit Name:

Inclusion:

Taxonomy:

Drainage Class:

Matrix Color:
Sawmill silty clay loam, Morley silt loam

Undetermined

Undetermined

Undetermined

10 YR 3/1, 10 YR 2.5/1, 10 YR 2/1.5, 10 YR 4.5/1 
Wetland Number: 303

Size: $30,538 \mathrm{~m}^{2}$ (7.546 acres)

Dominant Plant Species:

Scientific Name

Acer negundo

Carex cristatella

Carex vulpinoidea

Cornus racemosa

Equisetum arvense

Leersia oryzoides

Lonicera tatarica

Phragmites australis

Polygonum hydropiperoides

Rosa multiflora

Salix interior

Scirpus atrovirens

Typha angustifolia

Typha latifolia

Vitis riparia

\section{Common Name}

Box elder

Crested sedge

Fox sedge

Gray dogwood

Horsetail

Rice cut grass

Tartarian honeysuckle

Common reed

Mild water pepper

Multiflora rose

Willow

Dark green rush

Narrow-leaved cat-tail

Common cat-tail

Riverbank grape
Indicator

Status

FACW-

FACW+

OBL

FACW-

FAC

OBL

FACU

FACW +

OBL

FACU

OBL

OBL

OBL

OBL

FACW-

\section{Hydrology:}

Hydrologic Regime: Surface water is present throughout the year. Water levels are controlled by a beaver dam located at the northeast end on Freund Brook. Areas not inundated are saturated within $30 \mathrm{~cm}(12 \mathrm{in}$.) of the surface for extended periods. Water levels in this wetland vary considerably between years, depending on the condition of the beaver dam. Lower water levels allow wetland vegetation to colonize areas that under higher levels support only submergent aquatic plants and nonrooted floating plants.

Water Source(s): Freund Brook entering at the southwest end of the site, storm sewer system drainage from Buildings 200, 205, and 211 entering the site at the north end, and surface runoff from the surrounding area.

\section{Soil:}

Map Unit Name:

Inclusion:

Taxonomy:

Drainage Class:

Matrix Color:
Sawmill silty clay loam

Undetermined

Undetermined

Undetermined

10 YR 4.5/3, 10 YR 5/3.5, 10 YR 2/0 
Wetland Number: 304

Size: $2,046 \mathrm{~m}^{2}$ (0.506 acre)

Dominant Plant Species:

$\underline{\text { Scientific Name }}$

Acer negundo

Agrostis alba

Alisma subcordatum

Ambrosia trifida

Carex cristatella

Eupatorium serotinum

Geum canadense

Glyceria striata

Leersia oryzoides

Prunella vilgaris

Salix amygdaloides

Salix interior

Typha angustifolia

Vitis riparia

\section{Common Name}

Box elder

Redtop

Common water plantain

Giant ragweed

Crested sedge

Late boneset

White avens

Fowl meadow grass

Rice cut grass

Self heal

Peach-leaved willow

Sandbar willow

Narrow-leaved cat-tail

Riverbank grape
Indicator

Status

FACW-

FACW

OBL

FAC+

$\mathrm{FACW}+$

FAC+

FAC

OBL

OBL

FAC

FACW

OBL

OBL

FACW-

\section{Hydrology:}

Hydrologic Regime: Surface flow and standing water are present in spring.

Because of the high sediment load of the surface flow, the original soil surface has been overlaid with sediment, which is approximately $0.6 \mathrm{~m}(2 \mathrm{ft})$ thick in some areas.

Water Source(s): Surface runoff from the surrounding area and a seasonally high water table. Water from this wetland drains to wetland 302.

Soil:

Map Unit Name:

Inclusion:

Taxonomy:

Drainage Class:

Matrix Color:
Ashkum silty clay loam

Undetermined

Typic Haplaquoli

Poorly drained

10 YR 2/0, 10 YR 4/1, 2.5 Y 4/3 
Wetland Number: 305

Size: $1,809 \mathrm{~m}^{2}(0.447$ acre $)$

\section{Dominant Plant Species:}

Scientific Name

Bidens vulgata

Glyceria striata

Pilea pumila

Populus deltoides

Tovara virginiana

Vitis riparia

\section{Common Name}

Tall beggar's ticks

Fowl meadow grass

Clearweed

Cottonwood

Woodland knotweed

Riverbank grape
Indicator

Status

FACW

OBL

FACW

FAC+

FAC

FACW-

\section{Hydrology:}

Hydrologic Regime: Surface water is present for extended periods in spring.

Water Source(s): Surface runoff from the surrounding area and a seasonally high water table.

Soil:

Map Unit Name:

Inclusion:

Taxonomy:

Drainage Class:

Matrix Color:
Peotone silty clay loam

Undetermined

Cumulic Haplaquoll

Very poorly drained

10 YR $2 / 1$ 
Wetland Number: 306

Size: $1,480 \mathrm{~m}^{2}(0.366$ acre $)$

\section{Dominant Plant Species:}

$\underline{\text { Scientific Name }}$

Boehmeria cylindrica

Impatiens capensis

Pilea pumila

Typha angustifolia
Common Name

False nettle

Orange jewelweed

Clearweed

Narrow-leaved cat-tail
Indicator

Status

OBL

FACW

FACW

OBL

\section{Hydrology:}

Hydrologic Regime: Surface water is present throughout the growing season. Areas not inundated are saturated within $30 \mathrm{~cm}(12 \mathrm{in}$.) of the surface for extended periods in spring.

Water Source(s): Storm sewer drainage from the area of Building 212 entering at the north end of the site and surface runoff from the surrounding area.

Soil:

Map Unit Name:

Inclusion:

Taxonomy:

Drainage Class:

Matrix Color:
Peotone silty clay loam

Undetermined

Cumulic Haplaquoll

Very poorly drained

10 YR 3/1.5 
Wetland Numbe' : 307

Size: $2,776 \mathrm{~m}^{2}$ (0.686 acre)

Dominant Plant Species:

Scientific Name

Acer negundo

Acer saccharinum

Bidens frondosa

Boehmeria cylindrica

Cornus racemosa

Pilea pumila

Poa trivialis

Populus deltoides

Rhamnus cathartica

Rhus radicans

Ulmus americana

Vitis riparia
Common Name

Box elder

Silver maple

Common beggar's ticks

False nettle

Gray dogwood

Clearweed

Rough blue grass

Cottonwood

Buckthorn

Poison ivy

American elm

Riverbank grape
Indicator

Status

FACW-

FACW

FACW

OBL

FACW-

FACW

FACW

FAC+

FACU

FAC+

FACW-

FACW-

\section{Hydrology:}

Hydrologic Regime: Surface water is present over most of the site throughout the early part of the growing season but is absent by the end of the growing season. Areas not inundated are saturated to the surface for prolonged periods.

Water Source(s): Surface runoff from the surrounding area and a seasonally high water table.

Soil:

Map Unit Name:

Inclusion:

Taxonomy:

Drainage Class:

Matrix Color:
Blount silt loam

Ashkum

Typic Haplaquoll

Poorly drained

10 YR 2/0, 10 YR 2/1, 10 YR 2.5/1 
Wetland Number: 308

Size: $1,313 \mathrm{~m}^{2}$ (0.324 acre)

Dominant Plant Species:

Scientific Name

Agrostis alba

Carex vulpinoidea

Juncus torreyi

Phalaris arundinacea

Scirpus atrovirens

Typha angustifolia
Common Name

Redtop

Fox sedge

Torrey's rush

Reed canary grass

Dark green rush

Narrow-leaved cat-tail
Indicator

Status

FACW

OBL

FACW

FACW+

OBL

OBL

\section{Hydrology:}

Hydrologic Regime: Surface water is present for extended periods in spring. Areas not inundated are saturated within $30 \mathrm{~cm}$ (12 in.) of the surface for prolonged periods in spring.

Water Source(s): An unnamed intermittent stream entering at the west end of the site and surface runoff from the surrounding area.

Soil:

Map Unit Name:

Inclusion:

Taxonomy:

Drainage Class:

Matrix Color:
Morley silt loam

Undetermined

Undetermined

Undetermined

10 YR 2.5/2, 10 YR 4.5/3, 10 YR 4/4 
Wetland Number: 309

Size: $3,919 \mathrm{~m}^{2}$ (0.968 acre)

Dominant Plant Species:

Scientific Name

Carex bebbii

Elymus virginicus

Phalaris arundinacea

Ribes americanum

Scirpus atrovirens

Typha angustifolia
Common Name

Bebb's sedge

Virginia wild rye

Reed canary grass

Wild black currant

Dark green rush

Narrow-leaved cat-tail
Indicator

Status

OBL

FACW-

FACW+

FACW

OBL

OBL

\section{Hydrology:}

Hydrologic Regime: Surface water is present for prolonged periods in spring. Areas not inundated are saturated within $30 \mathrm{~cm}$ (12 in.) of the surface for prolonged periods in spring.

Water Source's): An intermittent drainage from the area of Building 362 entering the site at the north end and surface runoff from the surrounding area.

Soil:

Map Unit Name:

Inclusion:

Taxonomy:

Drainage Class:

Matrix Color:
Ashkum silty clay loam

Undetermined

Undetermined

Undetermined

10 YR 3/3, 10 YR 2.5/1.5, 10 YR 3/2 
Wetland Number: 401

Size: $1,816 \mathrm{~m}^{2}$ (0.449 acre)

Dominant Plant Species:

$\underline{\text { Scientific Name }}$

Bidens frondosa

Leersia oryzoides

Sparganium eurycarpum
Common Name

Common beggar's ticks

Rice cut grass

Common bur reed
Indicator

Status

FACW

OBL

OBL

\section{Hydrology:}

Hydrologic Regime: Surface water is present for most of the growing season. Areas not inundated are saturated to the surface for extended periods.

Water Source(s): Surface runoff from the surrounding area and a seasonally high water table.

\section{Soil:}

Map Unit Name:

Inclusion:

Taxonomy:

Drainage Class:

Matrix Color:
Morley silt loam

Ashkum

Typic Haplaquoll

Poorly drained

10 YR 2.5/1, 10 YR 2/0 
Wetland Number: 402

Size: $1,129 \mathrm{~m}^{2}$ (0.279 acre)

Dominant Plant Species:

Scientific Name

Bidens frondosa

Eupatorium serotinum

Leersia oryzoides

Pilea pumila
Common Name

Common beggar's ticks

Late boneset

Rice cut grass

Clearweed
Indicator

Status

FACW

FAC+

OBL

FACW

\section{Hydrology:}

Hydrologic Regime: Surface water is present throughout the year in a small area near the ANL-E boundary fence. The remainder of the site is saturated within $30 \mathrm{~cm}$ (12 in.) of the surface for extended periods.

Water Source(s): This wetland is part of a larger marsh in Waterfall Glen Forest Preserve. The marsh receives water from Freund Brook (draining from wetland $801 \mathrm{~B}$ in Waterfall Glen Forest Preserve) and surface runoff from the surrounding area.

Soil:

Map Unit Name: Peotone silty clay loam

Inclusion:

None

Taxonomy:

Cumulic Haplaquoll

Drainage Class: $\quad$ Very poorly drained

Matrix Color:

10 YR $2 / 0$ 
Wetland Number: 403

Size: $1,378 \mathrm{~m}^{2}(0.340$ acre $)$

Dominant Plant Species:

Scientific Name

Agrostis alba

Bidens frondosa

Carex scoparia

Eleocharis obtusa

Iris virginica shrevei

Leersia oryzoides

Penthorum sedoides

Polygonum coccineum
Common Name

Redtop

Common beggar's ticks

Pointed broom sedge

Blunt spikerush

Blue flag

Rice cut grass

Ditch stone crop

Water heartsease
Indicator

Status

\section{FACW}

FACW

FACW

OBL

OBL

OBL

OBL

OBL

\section{Hydrology:}

Hydrologic Regime: Surface water is present throughout the site in spring and early summer, but is absent by the end of the growing season.

Water Source(s): Surface runoff from the surrounding area and a seasonally high water table.

Soil:

Map Unit Name:

Inclusion:

Taxonomy:

Drainage Class:

Matrix Color:
Peotone silty clay loam

None

Cumulic Haplaquoll

Very poorly drained

10 YR 2/0 
Wetland Number: 404

Size: $1,217 \mathrm{~m}^{2}(0.301$ acre $)$

Dominant Plant Species:

Scientific Name

Bidens frondosa

Boehmeria cylindrica

Cornus racemosa

Glyceria striata

Pilea pumila

Vitis riparia

\section{Common Name}

Common beggar's ticks

False nettle

Gray dogwood

Fowl meadow grass

Clearweed

Riverbank grape
Indicator

Status

FACW

OBL

FACW-

OBL

FACW

FACW-

\section{Hydrology:}

Hydrologic Regime: Surface water is present for extended periods early in the growing season over much of the site but is absent by the end of the growing season. Areas not inundated are saturated within $30 \mathrm{~cm}(12 \mathrm{in}$.) of the surface for prolonged periods early in the growing season.

Water Source(s): Surface runoff from the surrounding area and a seasonally high water table.

Soil:

Map Unit Name: Inclusion:

Taxonomy: Drainage Class: Matrix Color:
Peotone silty clay loam Ashkum (in some areas) Cumulic Haplaquoll, Typic Haplaquoll Very poorly drained, poorly drained 10 YR 2.5/1 
Wetland Number: 405

Size: $5,194 \mathrm{~m}^{2}$ (1.283 acre)

\section{Dominant Plant Species:}

Scientific Name

Acer saccharinum

Glyceria septentrionalis

Impatiens capensis

Leersia virginica

Myriophyllum exalbescens

Sparganium eurycarpum
Common Name

Silver maple

Floating manna grass

Orange jewelweed

White grass

Spiked water milfoil

Common bur reed
Indicator

Status

FACW

OBL

FACW

FACW

OBL

OBL

\section{Hydrology:}

Hydrologic Regime: Surface water is present for most of the growing season.

Areas not inundated are saturated to the surface for extended periods.

Water Source(s): Surface runoff from the surrounding area and a seasonally high water table.

Soil:

Map Unit Name:

Inclusion:

Taxonomy:

Drainage Class:

Matrix Color:
Peotone silty clay loam, perennially ponded

None

Cumulic Haplaquoll

Very poorly drained

$10 \mathrm{YR} 2 / 0,10 \mathrm{YR} 2 / 1$ 
Wetland Number: 406

Size: $3,581 \mathrm{~m}^{2}$ (0.885 acre)

Dominant Plant Species:

Scientific Name

Agropyron repens

Agrostis alba

Ambrosia artemisiifolia elatior

Asclepias incarnata

Eupatorium serotinum

Carex cristatella

Carex tribuloides

Carex vulpinoidea

Cyperus esculentus

Phalaris arundinacea

Polygonum pensylvanicum laevigatum

\section{Common Name}

Quack grass

Redtop

Common ragweed

Swamp milkweed

Late boneset

Crested sedge

Blunt-broom sedge

Fox sedge

Chufa

Reed canary grass

Pennsylvania knotweed
Indicator

Status

FACU

FACW

FACU

OBL

FAC+

FACW+

FACW+

OBL

FACW

FACW+

FACW+

\section{Hydrology:}

Hydrologic Regime: Surface water is present for brief periods in spring. Soil is saturated within $30 \mathrm{~cm}$ (12 in.) of the surface in spring in the central portion of the site but infrequently in the outer portions. This site had been inundated in previous years for extended periods during the growing season, but the hydrology has recently been altered.

Water Source(s): Surface runoff from the surrounding area and a seasonally high water table.

Soil:

Map Unit Name:

Inclusion:

Taxonomy:

Drainage Class:

Matrix Color:
Peotone silty clay loam

None

Cumulic Haplaquoll

Very poorly drained

10 YR $2 / 0$ 
Wetland Number: 601

Size: $1,094 \mathrm{~m}^{2}(0.270$ acre $)$

Dominant Plant Species:

Scientific Name

Acer negundo

Bidens frondosa

Boehmeria cylindrica

Impatiens capensis

Leersia oryzoides

Lysimachia nummularia

Phalaris arundinacea

Pilea pumila

Polygonum punctatum

Rhus radicans

Rudbeckia laciniata

Salix alba

Scirpus atrovirens

Tilia americana

Ulmus americana

Vitis riparia
Common Name

Box elder

Common beggar's ticks

False nettle

Orange jewelweed

Rice cut grass

Moneywort

Reed canary grass

Clearweed

Smartweed

Poison ivy

Wild golden glow

White willow

Dark green rush

Basswood

American elm

Riverbank grape
Indicator

Status

FACW-

FACW

OBL

FACW

OBL

FACW+

FACW +

FACW

OBL

FAC+

FACW+

FACW

OBL

FACU

FACW-

FACW-

\section{Hydrology:}

Hydrologic Regime: Surface water is present in spring. Soil is saturated within $30 \mathrm{~cm}$ (12 in.) of the surface for prolonged periods for much of the remainder of the growing season.

Water Source(s): Freund Brook entering at the west end of the site, a small intermittent stream entering at the north, and surface runoff from the surrounding area.

Soil:

Map Unit Name:

Inclusion:

Taxonomy:

Drainage Class:

Matrix Color:
Morley silt loam

Undetermined

Undetermined

Undetermined

10 YR 2.5/2, 10 YR 2/1, 10 YR 2/0 
Wetland Number: 602

Size: $1,013 \mathrm{~m}^{2}$ (0.250 acre)

Dominant Plant Species:

Scientific Name

Apocynum sibiricum

Bidens cernua

Boehmeria cylindrica

Cyperus erythrorhizos

Echinochloa crusgalli

Eupatorium serotinum

Impatiens capensis

Leersia oryzoides

Phalaris arundinacea

Polygonum punctatum

Scutellaria lateriflora

Vitis riparia
Common Name

Indian hemp

Nodding bur marigold

False nettle

Red-rooted sedge

Barnyard grass

Late boneset

Orange jewelweed

Rice cut grass

Reed canary grass

Smartweed

Mad dog skullcap

Riverbank grape
Indicator

Status

FAC+

OBL

OBL

OBL

FACW

FAC+

FACW

OBL

FACW+

OBL

OBL

FACW-

\section{Hydrology:}

Hydrologic Regime: Surface water is present throughout the year. Areas not inundated are saturated within $30 \mathrm{~cm}$ (12 in.) of the surface for extended periods for much of the growing season.

Water Source(s): Freund Brook entering at the south end of the site and surface runoff from the surrounding area.

Soil:

Map Unit Name:

Inclusion:

Taxonomy:

Drainage Class:

Matrix Color:
Morley silt loam

Undetermined

Undetermined

Undetermined

5 Y 3.5/2, 2.5 Y $2 / 0,10$ YR 4/1 
Wetland Number: 603

Size: $7,724 \mathrm{~m}^{2}$ (1.909 acre)

Dominant Plant Species:

Scientific Name

Acer negundo

Acer saccharinum

Aster lateriflorus

Bidens cernua

Bidens frondosa

Boehmeria cylindrica

Carex vulpinoidea

Celastrus orbiculatus

Cirsium muticum

Cirsium arvense

Cornus racemosa

Eleocharis calva

Eupatorium serotinum

Fraxinus pennsylvanica

subintegerrima

Hibiscus palustris

Impatiens capensis

Leersia oryzoides

Lobelia siphilitica

Lonicera japonica

Parthenocissus quinquefolia

Phalaris arundinacea

Phragmites australis

Polygonum punctatum

Potamogeton nodosus

Rhus radicans

Ribes americanum

Rosa multiflora

Rubus occidentalis

Rudbeckia laciniata

Sagittaria latifolia

Salix amygdaloides

Scirpus atrovirens

Typha angustifolia

Ulmus americana

Vitis riparia
Common Name

Box elder

Silver maple

Side-flowered aster

Nodding bur marigold

Common beggar's ticks

False nettle

Fox sedge

Oriental bittersweet

Swamp thistle

Canada thistle

Gray dogwood

Bald spikerush

Late boneset

Green ash

Swamp rose mallow

Orange jewelweed

Rice cut grass

Great blue lobelia

Japanese honeysuckle

Virginia creeper

Reed canary grass

Common reed

Smartweed

Long-leaved pondweed

Poison ivy

Wild black currant

Multiflora rose

Black raspberry

Wild golden glow

Common arrowhead

Peach-leaved willow

Dark green rush

Narrow-leaved cat-tail

American elm

Riverbank grape
Indicator

Status

FACW-

FACW

FACW-

OBL

FACW

OBL

OBL

No indicator

OBL

FACU

FACW-

OBL

FAC+

FACW

OBL

FACW

OBL

FACW +

FACU

FAC-

FACW+

FACW+

OBL

OBL

FAC+

FACW

FACU

UPL

FACW+

OBL

FACW

OBL

OBL

FACW.

FACW- 
Wetland Number 603 (cont.)

\section{Hydrology:}

Hydrologic Regime: Surface water is present throughout the growing seacon at lower elevations. Remaining areas are saturated within $30 \mathrm{~cm}(12 \mathrm{in}$.) of the surface for prolonged periods in spring.

Water Source(s): Freund Brook entering at the southwest end of the site, an intermittent stream entering at the northwest (originating at wetland 207 and also receiving drainage from the area of Building 212), and surface runoff from the surrounding area.

Soil:

Map Unit Name: Inclusion:

Taxonomy:

Drainage Class: Matrix Color:
Morley silt loam, Sawmill silty clay loam

Undetermined

Cumulic Haplaquoll (Sawmill)

Poorly drained (Sawmill)

2.5 Y 2.5/0, 5 YR 2/0, 5 Y 3/1, 10 YR 3/1, 10 YR 3/1.5, 2.5 Y 3/1, 2.5 Y 3.5/1, 10 YR 2.5/1, 10 YR 4/1.5 
Wetland Number: 801A

Size: $7,457 \mathrm{~m}^{2}$ (1.843 acres)

Dominant Plant Species:

Scientific Name

Agrostis alba

Phalaris arundinacea

Phragmites australis

Polygonum coccineum

Populus deltoides

Salix interior

Scirpus atrovirens

Typha angustifolia
Common Name

Redtop

Reed canary grass

Common reed

Water heartsease

Cottonwood

Sandbar willow

Dark green rush

Narrow-leaved cat-tail
Indicator

Status

FACW

FACW+

FACW+

OBL

FAC+

OBL

OBL

OBL

\section{Hydrology:}

Hydrologic Regime: Surface water is present throughout the growing season. Areas not inundated are saturated within $30 \mathrm{~cm}$ (12 in.) of the surface for extended periods in spring. Hydrologically connected (through culvert) to off-site wetland 801B.

Water Source(s): Surface runoff from the surrounding area.

Soil:

Map Unit Name:

Inclusion:

Taxonomy:

Drainage Class:

Matrix Color:
Peotone silty clay loam

Undetermined

Undetermined

Undetermined

10 YR 3.5/2, 10 YR 4/2, 10 YR 2/1, 10 YR 3.5/1.5 
Wetland Number: 801B (off-site)

Size: $41,345 \mathrm{~m}^{2}$ (10.216 acres)

Dominant Plants:

Scientific Name

Acer negundo

Alliaria officinalis

Bidens frondosa

Geum canadense

Lycopus americanus

Phalaris arundinacea

Pilea pumila

Populus deltoides

Penthorum sedoides

Rhamnus cathartica

Typha angustifolia

Typha latifolia

\section{Common Name}

Box elder

Garlic mustard

Common beggar's ticks

White avens

Common water horehound

Reed canary grass

Clearweed

Cottonwood

Ditch stonecrop

Common buckthorn

Narrow-leaved cat-tail

Common cat-tail
Indicator

Status

FACW-

FAC

FACW

FAC

OBL

FACW+

FACW

FAC+

OBL

FACU

OBL

OBL

\section{Hydrology:}

Hydrologic Regime: Surface water occurs throughout the growing season over much of this site. The remaining areas are saturated to the surface for extended periods. Hydrologically connected (through culvert) to on-site wetland 801A.

Water Source(s): Surface runoff from the surrounding area and a high water table. This site appears to be the headwaters of Freund Brook.

Soil:

Map Unit Name:

Inclusion:

Taxonomy:

Drainage Class:

Matrix Color:
Peotone silty clay loam

Undetermined

Cumulic Haplaquoll

Very poorly drained

10 YR 3/1, 10 YR 2/0 
Wetland Number: 802

Size: $5,864 \mathrm{~m}^{2}$ (1.449 acres)

Dominant Plant Species:

Scientific Name

Agrostis alba

Ambrosia trifida

Andropogon gerardii

Bidens aristosa

Boehmeria cylindrica

Carex cristatella

Carex lanuginosa

Carex vulpinoidea

Cornus racemosa

Cornus stolonifera

Eupatorium serotinum

Juncus torreyi

Phalaris arundinacea

Phleum pratense

Populus deltoides

Pycnanthemum virginianum

Salix interior

Scirpus atrovirens

Spartina pectinata

Vitis riparia
Common Name

Redtop

Giant ragweed

Big bluestem

Swamp marigold

False nettle

Crested sedge

Wooly sedge

Fox sedge

Gray dogwood

Red-osier dogwood

Late boneset

Torrey's rush

Reed canary grass

Timothy

Cottonwood

Mountain mint

Sandbar willow

Dark green rush

Prairie cord grass

Riverbank grape
Indicator

Status

FACW

FAC+

FAC-

FACW

OBL

FACW+

OBL

OBL

FACW-

FACW

FAC+

FACW

FACW+

FACU

FAC+

FACW+

OBL

OBL

FACW+

FACW-

\section{Hydrology:}

Hydrologic Regime: Surface water is present for extended periods in spring in the drainage channel. Areas not inundated are saturated within $30 \mathrm{~cm}$ (12 in.) of the surface for prolonged periods in spring.

Water Source(s): Surface runoff from the surrounding area, a small drainage from the landfill area originating at the west end of the site, and storm sewer drainage from the 800 Area entering at the northwest.

Soil:

Map Unit Name:

Inclusion:

Taxonomy:

Drainage Class:

Matrix Color:
Ashkum silty clay loam, Morley silt loam

Undetermined

Typic Haplaquoll

Poorly drained

10 YR 2.5/0.5, 10 YR 2/0, 10 YR 2/1, 10 YR 2.5/1, 10 YR 5/4 
Wetland Number: 803

Size: $10,840 \mathrm{~m}^{2}$ (2.679 acres)

Dominant Plant Species:

Scientific Name

Agrostis alba

Carex uulpinoidea

Cirsium arvense

Eleocharis calva

Iris virginica shrevei

Poa pratensis

Salix interior

Scirpus americanus

Scirpus atrovirens

Spartina pectinata

Stachys palustris homotricha

Teucrium occidentale

Typha angustifolia
Common Name

Redtop

Fox sedge

Canada thistle

Bald spikerush

Blue flag

Kentucky blue grass

Sandbar willow

Chairmaker's rush

Dark green rush

Prairie cord grass

Woundwort

Germander

Narrow-leaved cat-tail
Indicator

Status

FACW

OBL

FACU

OBL

OBL

FAC.

OBL

OBL

OBL

FACW+

OBL

FACW.

OBL

\section{Hydrology:}

Hydrologic Regime: Surface water is present throughout the growing season. Areas not inundated are saturated within $30 \mathrm{~cm}$ (12 in.) of the surface for extended periods in spring.

Water Source(s): Storm sewer drainage from the 800 Area and the area of Building 200, drainage from wetlands 802 and 804 , and surface runoff from the surrounding area.

Soil:

Map Unit Name:

Inclusion:

Taxonomy:

Drainage Class:

Matrix Color:
Peotone silty clay loam

Undetermined

Cumulic Haplaquoll

Very poorly drained

10 YR 2/1, 10 YR 3/1, 10 YR 5.5/4 
Wetland Number: 804

Size: $3,292 \mathrm{~m}^{2}$ (0.813 acre)

Dominant Plant Species:

Scientific Name

Bidens vulgata

Boehmeria cylindrica

Carex vulpinoidea

Carex cristatella

Carex lanuginosa

Leersia oryzoides

Lemna minor

Phalaris arundinacea

Pilea pumila

Populus deltoides

Typha angustifolia

Vitis riparia
Common Name

Tall beggar's ticks

False nettle

Fox sedge

Crested sedge

Wooly sedge

Rice cut grass

Small duckweed

Reed canary grass

Clearweed

Cottonwood

Narrow-leaved cat-tail

Riverbank grape
Indicator

Status

FACW

OBL

OBL

FACW +

OBL

OBL

OBL

FACW +

FACW

FAC+

OBL

FACW.

\section{Hydrology:}

Hydrologic Regime: Surface water is present for extended periods in spring. Areas not inundated are saturated to the surface for prolonged periods in spring.

Water Source(s): A seasonally high water table, drainage from an excavated channel entering at the northwest, and surface runoff from the surrounding area.

Soil:

Map Unit Name:

Inclusion:

Taxonomy:

Drainage Class:

Matrix Color:
Peotone silty clay loam

Undetermined

Cumulic Haplaquoll

Very poorly drained

10 YR 2.5/1, 10 YR 2/1, 10 YR 3/2 


\section{DISCUSSION}

This study of wetlands has identified the location, size, and characteristics of jurisdictional wetlands at the ANL-E site and provides valuable information for site planning and management. Project managers can use the information on location to aid in planning projects so as to avoid impacting wetlands. In those cases where impacts cannot be avoided, information on wetland size and other characteristics can be used in preparing applications for authorization of the proposed activity under Section 404 of the Clean Water Act and in preparing a wetlands assessment for compliance with 10 CFR Part 1022.

Although many potential impacts to wetlands are direct (e.g., location of an action within the boundaries of the wetland) and can be easily avoided in siting projects, wetlands are also susceptible to indirect impacts. Such indirect impacts usually result from impacts to the drainage basin of wetlands and include the runoff of sediment and other contaminants from construction sites and the alteration of a wetland's hydrology. Information on wetland hydrology is presented in this report to enable an evaluation of these indirect impacts. Any action that would affect the water source of wetlands (as presented in "Results") would require a wetlands assessment.

The results of this delineation should be used with caution for several reasons. First, wetlands change over time as a result of natural or human-induced changes in hydrological conditions (e.g., beaver activity or laboratory operations) and natural plant succession. Thus, the wetland boundaries and dominant plant species presented in this report should not be considered permanent.

Second, wetlands smaller than $500 \mathrm{~m}^{2}$ occur within the ANL-E boundary, but delineating these sites was beyond the scope of this project. Thus, the total wetland acreage given here ( 18.1 ha [44.6 acres]) is not the total wetland acreage on the ANL-E site, and the smaller wetlands should be delineated, as appropriate, for development projects.

Third, inaccuracies in the ANL-E site map on which wetland boundaries were digitized may lead to apparent inaccuracies in Plate 1 with regard to the location of these wetlands. The site map used contains many inaccuracies regarding the locations of roads, buildings, stream channels, and other features. To minimize problems, the locations of the wetlands were digitized onto the map relative to objects that appeared to be accurately located on the basis of aerial photographs, such as the corner of a building. For example, wetland 204, which parallels Outer Circle Road, is accurately placed relative to the Visitor's Center at the Northgate Entrance, but inaccuracies in the original mapping of the road result in part of the wetland overlapping the ruad in Plate 1.

Although these problems exist, this delineation is useful. To avoid problems with shifting wetland boundaries and conditions, we recommend periodic reevaluation of wetland boundaries (every five years) or for any new proposed projects. New proposals should also be evaluated for impacts to wetlands smaller than $500 \mathrm{~m}^{2}$ that were not delineated for this 
report. Because of the complexity of wetlands, we suggest that potential impacts to wetlands always be evaluated by a qualified wetlands scientist.

\section{REFERENCES}

Environmental Laboratory, 1987, Corps of Engineers Wetlands Delineation Manual, Technical Report Y-87-1, U.S. Army Engineer Waterways Experiment Station, Vicksburg, Miss.

Kollmorgen Corporation, 1990, Munsell Soil Color Charts, Macbeth Division of Kollmorgen Corporation, Baltimore, Md.

Reed, P.B., Jr., 1988, National List of Plant Species that Occur in Wetlands: North Central (Region 3), U.S. Fish and Wildlife Service Biological Report 88 (26.3).

Soil Conservation Service, 1979, Soil Survey of DuPage and Part of Cook Counties, Illinois, U.S. Department of Agriculture, Illinois Agricultural Experiment Station Report No. 108.

Swink, F., and G. Wilhelm, 1979, Plants of the Chicago Region, The Morton Arboretum, Lisle, III. 


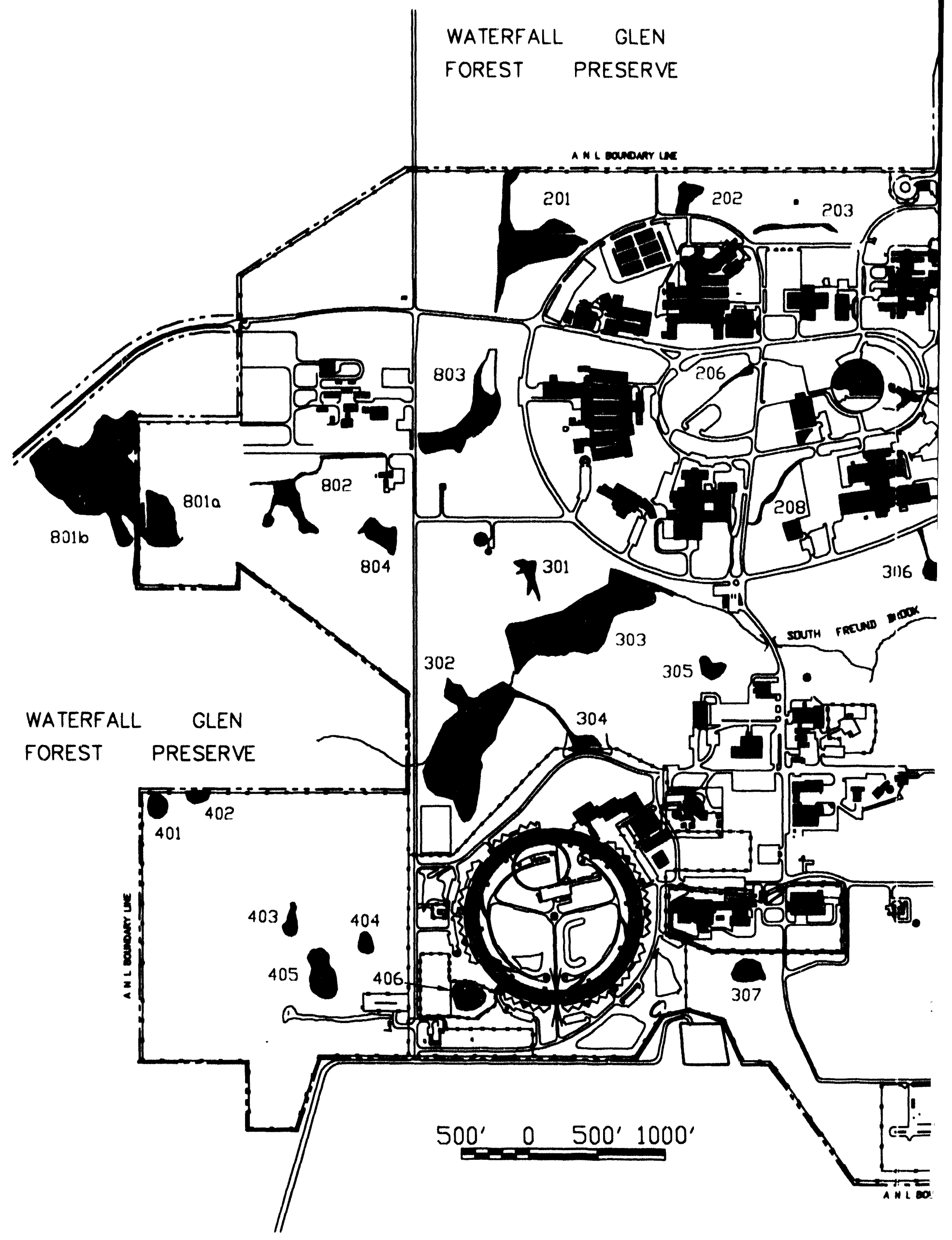




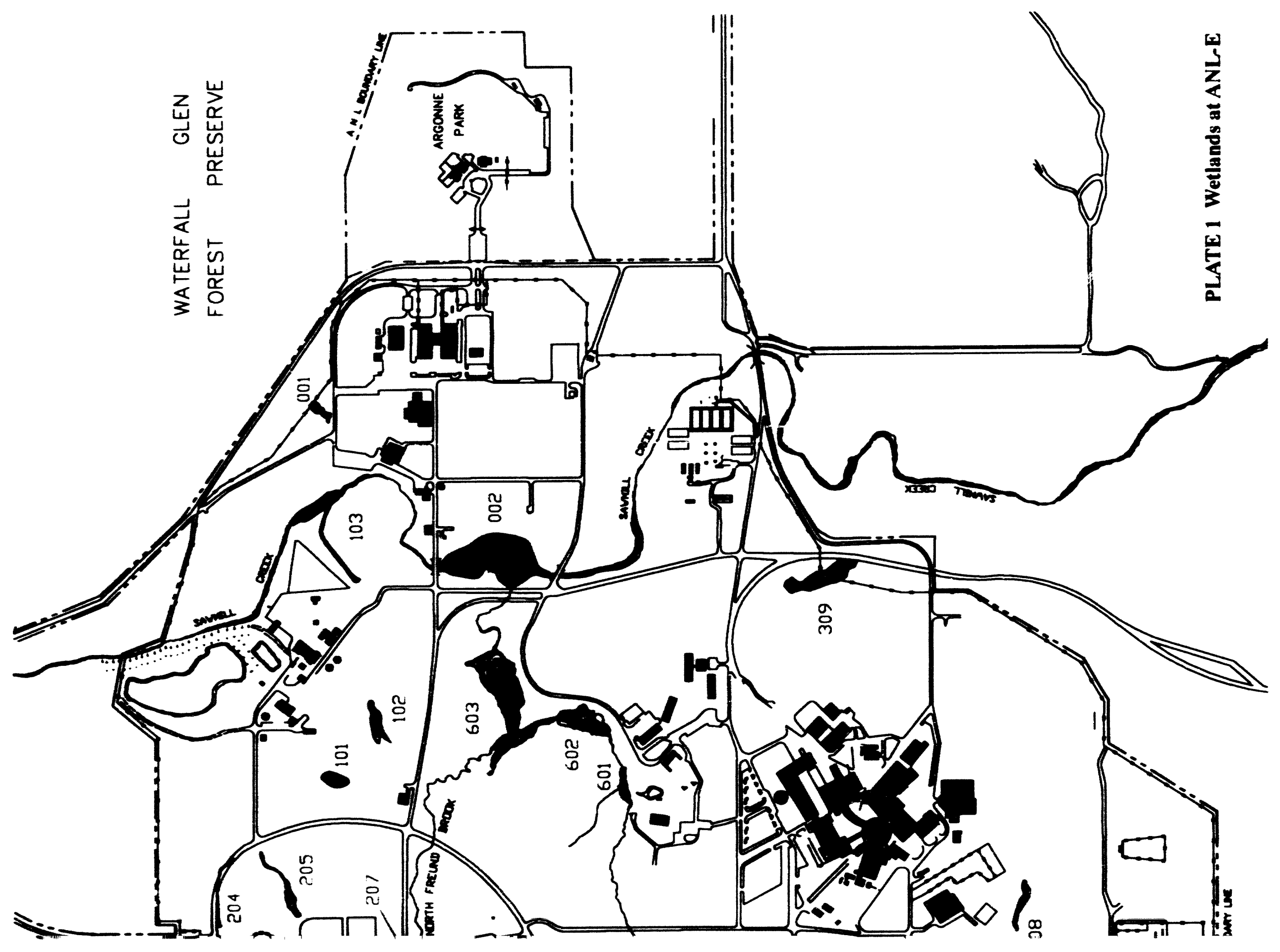



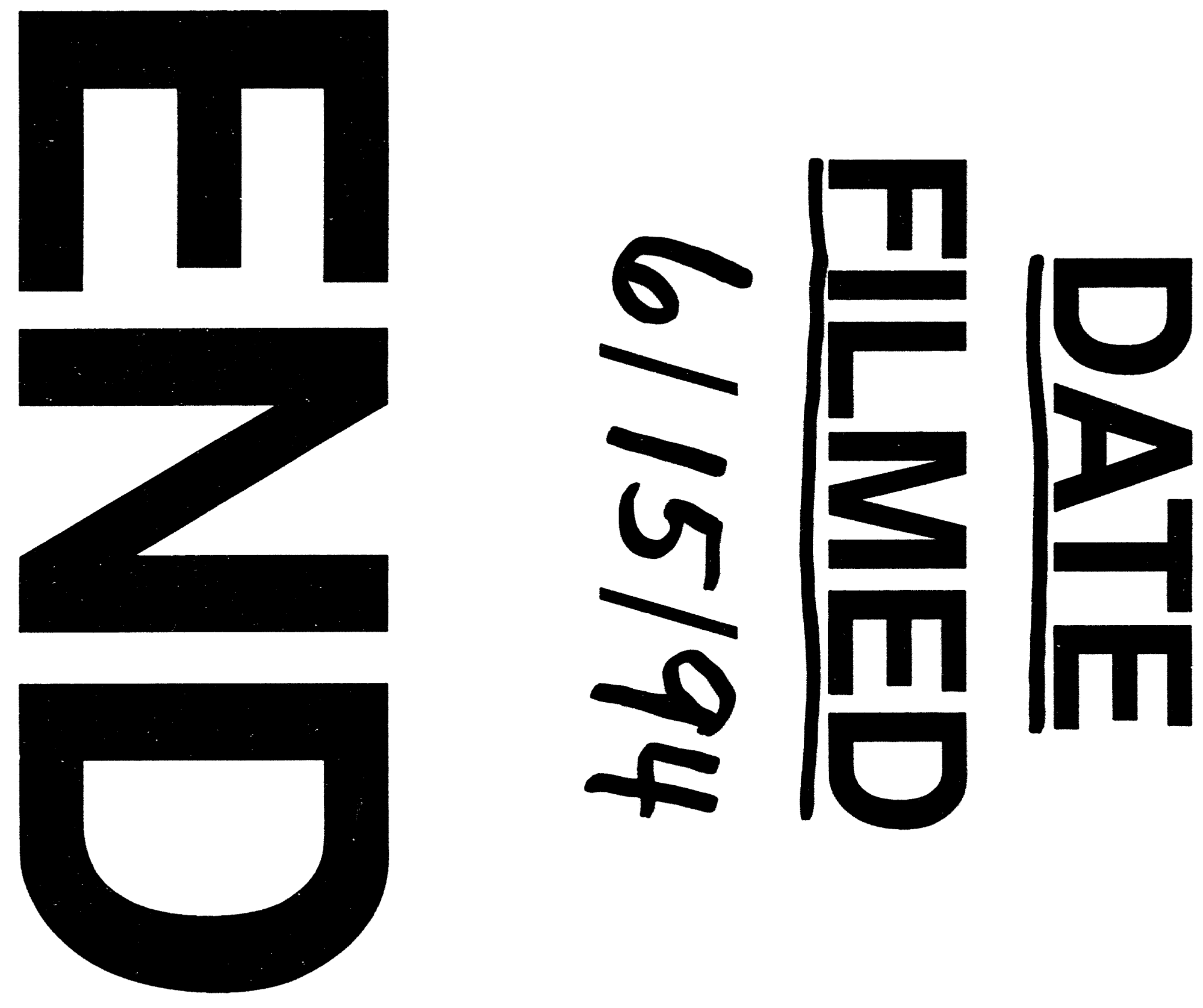
